\title{
BMJ Open Short-term effects of cold spells on hospitalisations for acute exacerbation of chronic obstructive pulmonary disease: a time-series study in Beijing, China
}

\author{
Yanbo Liu, ${ }^{1}$ Yuxiong Chen, ${ }^{1}$ Dehui Kong, ${ }^{1}$ Xiaole Liu, ${ }^{1}$ Jia Fu (D) , ${ }^{1}$ Yongqiao Zhang, \\ Yakun Zhao, ${ }^{1}$ Zhen'ge Chang, ${ }^{1}$ Xiaoyi Zhao, ${ }^{2}$ Kaifeng Xu, ${ }^{1}$ Chengyu Jiang, ${ }^{3}$ \\ Zhongjie Fan (1) ${ }^{1}$
}

To cite: Liu Y, Chen Y, Kong D, et al. Short-term effects of cold spells on hospitalisations for acute exacerbation of chronic obstructive pulmonary disease: a time-series study in Beijing, China. BMJ Open 2021;11:e039745. doi:10.1136/ bmjopen-2020-039745

- Prepublication history and supplemental material for this paper are available online. To view these files, please visit the journal online (http://dx.doi. org/10.1136/bmjopen-2020039745).

$\mathrm{YL}$ and $\mathrm{YC}$ contributed equally.

Received 24 April 2020

Revised 10 September 2020

Accepted 09 November 2020

Check for updates

(C) Author(s) (or their employer(s)) 2021. Re-use permitted under CC BY. Published by BMJ.

For numbered affiliations see end of article.

Correspondence to Professor Zhongjie Fan; Fanzhongjie@pumch.cn

\section{ABSTRACT}

Objectives Our work aimed at exploring the relationship between cold spells and acute exacerbation of chronic obstructive pulmonary disease (AECOPD) hospitalisations in Beijing, China, and assessing the moderating effects of the intensities and the durations of cold spells, as well as identifying the vulnerable.

Design A time-series study.

Setting We obtained time-series data of AECOPD hospitalisations, meteorological variables and air quality index in Beijing, China during 2012-2016.

Participants All AECOPD hospitalisations among permanent residents in Beijing, China during the cold seasons (November-March) of 2012-2016 were included $(n=84571)$.

Primary and secondary outcome measures A quasiPoisson regression with a distributed lag model was fitted to investigate the short-term effects of cold spells on AECOPD hospitalisations by comparing the counts of AECOPD admissions during cold spell days with those during non-cold spell days.

Results Cold spells under different definitions were associated with increased risk of AECOPD hospitalisations, with the maximum cumulative relative risk (CRR) over 3 weeks (lag0-21). The cumulative effects at lag0-21 increased with the intensities and the durations of cold spells. Under the optimal definition, the most significant single-day relative risk (RR) was found on the days of cold spells (lag0) with an RR of 1.042 (95\% Cl 1.013 to 1.072), and the CRR at lag0-21 was $1.394(95 \% \mathrm{Cl} 1.193$ to 1.630). The elderly (aged $\geq 65$ ) were more vulnerable to the effects of cold spells on AECOPD hospitalisations.

Conclusion Cold spells are associated with increased AECOPD hospitalisations in Beijing, with the cumulative effects increased with intensities and durations. The elderly are at particular risk of AECOPD hospitalisations triggered by cold spells.

\section{INTRODUCTION}

The Intergovernmental Panel on Climate Change has predicted that human activities
Strengths and limitations of this study

- This study was the first to examine the association between cold spells and acute exacerbation of chronic obstructive pulmonary disease (AECOPD) hospitalisations in China.

- The study assessed the effects of cold spells under different definitions on AECOPD hospitalisations to find out the optimal cold spell definition on the issue.

- The ecological design cannot imply causality definitely, while limited information on individual-level factors and inevitable exposure measurement errors may lead to bias.

The data from one specific city limited the extrapolation of the findings.

and global climate change will cause variations in frequency, intensity and duration of many extreme weather events, including heatwaves and cold spells. ${ }^{1}$ Although the amount of cold spells may decrease over most land areas due to global warming, a few recent studies found that the persistent shift of the Arctic polar vortex and the Arctic amplification associated with global warming could lead to increased extremely cold events in mid-latitudes. ${ }^{23}$ Over the last few years, the impacts of cold spells on human health have gained growing attention from the public. Many studies have reported positive relationships between cold spells and mortality, ${ }^{4-6}$ while the impacts of cold spells on hospital visits or admissions are underexamined.

Chronic obstructive pulmonary disease (COPD) is one of the common respiratory diseases characterised by poorly reversible limitation of airflow. ${ }^{7}$ Owing to its high prevalence, morbidity, mortality and economic burden globally, COPD has been an important 
public health concern and will remain a huge challenge for healthcare practitioners in the foreseeable future. ${ }^{8}$ Thus, it is crucial to identify the risk factors of COPD to improve strategies on prevention and intervention. Given the projected climate change, extreme temperature events potentially pose threats to patients with COPD. Many epidemiological studies have indicated that COPD has higher rates of exacerbation and hospitalisation with lower temperatures. ${ }^{9-13}$ We hypothesised that cold spells, defined as prolonged periods of extremely cold weather, may be more detrimental to patients with COPD and could cause more hospitalisations for acute exacerbations of chronic obstructive pulmonary disease (AECOPD). ${ }^{14}$ However, few studies have been carried out on the association between cold spells and AECOPD hospitalisations. ${ }^{15}$

As the world's largest country by population, China shoulders the enormous burden of COPD. A national cross-sectional study from 2012 to 2015 showed that the prevalence of COPD among Chinese adults aged 20 years and older was $8.6 \%$ (an estimated 99.9 million patients with COPD) ${ }^{16}$ On the other hand, with most areas located in mid-latitudes, China has experienced several severe cold spells in recent years. The cold spells in 2008 resulted in a significantly higher all-cause mortality in subtropical China and estimated losses exceeding $\$ 22.3$ billion. ${ }^{17} 18$ Moreover, the public now has a better perception of the potential risks of extreme temperatures in China, especially those with chronic conditions. ${ }^{19}$ Since no relevant studies have been reported in China, it is of great value to assess the association between cold spells and AECOPD hospitalisations to build prevention and adaption strategies suitable to local conditions (eg, climate type, sociodemographic status of residents), which may be different from other regions.

Cold spells have been defined differently due to the heterogeneity of climate and people's adaptive capacities in different regions. Previous studies suggested that the effects of cold spells varied by different cold spell characteristics and individual-specific factors. ${ }^{20} 21$ We have three main objectives in this work: (1) to illuminate the short-term effects of cold spells on the risk of hospitalisations for AECOPD with time-series methods; (2) to investigate the effect modification of cold spell intensities and durations by fitting different definitions and to explore the optimal cold spell definition in this region; and (3) to identify potentially vulnerable populations through stratified analyses. The results could help better understand the relationship between extremely cold events and AECOPD hospitalisations, and provide scientific evidence in policymaking for local prevention and intervention of AECOPD.

\section{MATERIALS AND METHODS}

\section{Data collection}

Beijing, the capital of China, is located in the northern part of China $\left(39^{\circ} 56^{\prime} \mathrm{N}, 116^{\circ} 20^{\prime} \mathrm{E}\right)$. The area covers $16410.54 \mathrm{~km}^{2}$, with more than 21 million population in 2016. Beijing has a typical semihumid continental monsoon climate with four distinctive seasons.

Daily hospitalisations for AECOPD from 1 January 2012 to 31 December 2016 were collected from the Beijing Public Health Information Center (http://www. phic.org.cn/). All government and private hospitals at the secondary or tertiary level in Beijing are required to submit their discharge records to the database ${ }^{22}{ }^{23}$ Each record consists of the following information: admission date, discharge date, age, gender, address, diagnosis and International Classification of Diseases 10th revision (ICD-10) diagnostic code. We excluded records with missing or wrong information on residential addresses. Only those among Beijing residents admitted to hospitals with AECOPD as the primary discharge diagnosis (ICD10: J44) were included in the study. ${ }^{23}$ All data for the analysis were anonymous at collection.

We collected the daily 2012-2016 meteorological data in Beijing from the China Meteorological Data Sharing Service System, including daily mean temperature $\left({ }^{\circ} \mathrm{C}\right)$, daily mean relative humidity $(\%)$ and daily mean air pressure $(\mathrm{hPa})$. For the same period, the daily air quality index (AQI) was obtained from the China National Environmental Monitoring Centre. The AQI value denotes the maximum value of individual air quality indexes of six monitored air pollutants (particulate matter with aerodynamic diameter $<2.5 \mu \mathrm{m}$, particulate matter with aerodynamic diameter $<10 \mu \mathrm{m}$, nitrogen dioxide, sulfur dioxide, carbon monoxide and ozone). Considering the impact of influenza viral infections on AECOPD, ${ }^{13}{ }^{24}$ we also accessed data on virological surveillance from the Chinese National Influenza Center (CNIC) (http://www. chinaivdc.cn/cnic/). The CNIC monitors the activity of seasonal influenza viruses in China and reports weekly positive rates of influenza isolations in the northern and southern parts separately. In this study, the onset of influenza epidemics (a binary variable representing days with relatively high influenza episodes ${ }^{25} 26$ was defined as when the proportion of isolates positive for influenza in any given week exceeded $30 \%$ of the maximum weekly positive isolation rate in the whole surveillance season (influenza surveillance season was defined from the 27th week of the previous year to the 26th week of the following year) in northern China. ${ }^{27}$

\section{Cold spell definitions}

The definition of cold spells varied across the research field due to distinct climatic features and temperature variations in different regions. As to the prior studies, cold spells were usually defined based on temperature thresholds and durations. ${ }^{41528}$ Instead of specific temperatures as thresholds, percentiles of temperature were shown to have a better model fit according to quasi-Poisson Akaike information criterion (Q-AIC). ${ }^{6}$ Moreover, some researchers suggested that daily mean temperature is superior to the minimum or maximum temperature as an indicator to define cold spells because it reflects the exposure throughout the day rather than a short 
period. ${ }^{20}{ }^{29}$ Therefore, we defined cold spell episodes as days when the daily mean temperature was at or below the 10 th, 5 th or 3 rd percentile for at least 2,3 or 4 consecutive days of the study period. ${ }^{21}$ To avoid possible biases caused by a few extreme summer events, we restricted the study period to the five coldest adjacent months (from November of the previous year to March of the following year) for each year. ${ }^{61520}$ Cold spell was treated as a dichotomous variable, with a value of 1 during the cold spell period. Statistical analyses were performed separately for each definition of cold spells.

\section{Statistical methods}

In the analyses, the dependent variable was the number of daily AECOPD hospitalisations following a quasiPoisson distribution. Hence, we adopted a distributed lag model (DLM) ${ }^{30}$ with a quasi-Poisson generalised linear regression model. To investigate the effects of cold spells on AECOPD hospitalisations, we compared the counts of AECOPD admissions during cold spell days with those during non-cold spell days, after adjusting for relative humidity, atmospheric pressure, AQI, seasonality, longterm trends, statutory holiday, influenza epidemics and day of the week. The Q-AIC was employed to choose the optimal cold spell definition and df. The model was established as follows:

$$
\begin{aligned}
& \mathrm{Y}_{\mathrm{t}} \sim \text { quasiPoisson }\left(\mu_{\mathrm{t}}\right) \\
& \log \left(\mu_{\mathrm{t}}\right)=\alpha+\operatorname{cb}\left(\mathrm{CS}_{\mathrm{t}}, \mathrm{lag}, \mathrm{df}=3\right)+ \\
& \mathrm{ns}\left(\mathrm{RH}_{\mathrm{t}}, \mathrm{df}=3\right)+\mathrm{ns}\left(\mathrm{AP}_{\mathrm{t}}, \mathrm{df}=3\right)+ \\
& \text { ns }\left(\mathrm{AQI}_{\mathrm{t}}, \mathrm{df}=3\right)+\mathrm{ns}\left(\text { Time }_{\mathrm{t}}, \mathrm{df}=3 / \text { per year }\right)+\gamma \mathrm{DOW}_{\mathrm{t}}+ \\
& \delta \text { Holiday }_{\mathrm{t}}+\nu \text { Influenza }_{\mathrm{t}} \text {, }
\end{aligned}
$$

where $t$ is the day of observation; $\mathrm{Y}_{t}$ is the expected number of hospitalisations for AECOPD on day $t ; \alpha$ is the intercept; $\mathrm{CS}_{\mathrm{t}}$ denotes the cold spells on day $\mathrm{t}(0=$ noncold spell days and $1=$ cold spell days); and cb represents the cross-basis function, including a linear function and a natural cubic spline function with $3 \mathrm{df}$ to assess the linear and lagged effects of the cold spells separately. We fitted a lag structure up to 21 days in the models to completely capture the flexible lagged effects of cold spells exposure. ns refers to the natural cubic spline function. ns with $3 \mathrm{df}$ was applied for the mean relative humidity $\left(\mathrm{RH}_{\mathrm{t}}\right)$, mean atmospheric pressure $\left(\mathrm{AP}_{\mathrm{t}}\right)$ and air quality index $\left(\mathrm{AQI}_{\mathrm{t}}\right)$, respectively. ns with $3 \mathrm{df}$ per year was used to control the seasonality and long-term trends. DOW $_{t}$ is a categorical variable indicating the day of the week on day $\mathrm{t}$, and $\gamma$ is the coefficient. Holiday $y_{t}$ is a binary variable $(0=$ nonstatutory holiday and $1=$ statutory holiday) and $\delta$ is the coefficient. Influenza is a dichotomous variable with the value of ' 1 ' for the influenza epidemic on day $t$, and $v$ is the coefficient. The statistical methods, maximum lag days and confounding factors included in the model were commonly used and described in previous publications. ${ }^{41720213132}$

To observe the variation trend of lagged effects, we calculated the single-day lagged effects (from lag0 to lag21) and cumulative effects (lag0, lag0-7, lag0-14 and lag0-21) of cold spells on AECOPD hospitalisations, respectively. To identify the susceptible subpopulations for more targeted public health interventions, we further conducted subgroup analyses to investigate the potential modification effects by gender (male and female) and age ( $0-64$ years old and $\geq 65$ years old) under the optimal definition of cold spells. The statistical differences of the risk estimates between the subgroups were examined by Z-test with the following equation:

$$
\mathrm{Z}=\left(\mathrm{E}_{1}-\mathrm{E}_{2}\right) / \sqrt{\left(\mathrm{SE}_{1}^{2}+\mathrm{SE}_{2}^{2}\right)}
$$

where $\mathrm{Z}$ represents the $\mathrm{Z}$-test value; $\mathrm{E}_{1}$ and $\mathrm{E}_{2}$ denote the effect estimates of two categories; and $\mathrm{SE}_{1}$ and $\mathrm{SE}_{2}$ are the corresponding standard errors of $E_{1}$ and $E_{2}$.

\section{Sensitivity analysis}

We performed the sensitivity analyses by altering the $\mathrm{df}$ with 3-5 df per year of the long-term trend, $3-5 \mathrm{df}$ of the relative humidity, 3-5 df of the air pressure, 3-5 df of the AQI and 3-5 df of the lag dimension in the DLM under the optimal definition of cold spells. We used R V.3.6.1 software with the 'dlnm' and 'splines' packages to run the analyses. All statistical tests were two-sided and values of $\mathrm{p}<0.05$ were considered statistically significant.

\section{Patient and public involvement}

Patients were not involved in the development of the research question and outcome measures, study design, or conduct of this study.

\section{RESULTS}

\section{Data description}

Table 1 shows the descriptive statistics of the study population, the meteorological variables and the AQI during the cold seasons (November-March) from 2012 to 2016 in Beijing. There were a total of 84571 AECOPD hospitalisations throughout the study period. Among these cases, $63.6 \%$ were male and $36.4 \%$ were female. Of all patients, $83.9 \%$ were aged 65 years and above. The average daily mean temperature, relative humidity, air pressure and AQI were $0.9^{\circ} \mathrm{C}$ (range, $-16.0^{\circ} \mathrm{C}$ to $18.0^{\circ} \mathrm{C}$ ), $46.6 \%$ (range, $8.0 \%-98.0 \%$ ), $1025.3 \mathrm{hPa}$ (range, 1005.0-1044.0 hPa) and 126.3 (range, 17.0-485.0), respectively.

Table 2 shows the overview information of cold spells under different definitions. More days were defined as cold spell days with higher temperature thresholds and shorter duration. We observed the most cold spell episodes and days in 4years using the definition of periods of at least 2 days with daily mean temperature below or at the 10 th percentile $\left(-6^{\circ} \mathrm{C}\right)$. In contrast, there were only two cold spell episodes (10 cold spell days) if we defined cold spells as periods of 4 or more consecutive days when the daily mean temperature was below or at the third percentile $\left(-8^{\circ} \mathrm{C}\right)$. 
Table 1 Statistics summary of daily hospitalisations for AECOPD (counts per day), meteorological variables and air quality index during cold seasons (November-March) in Beijing, China, 2012-2016

\begin{tabular}{|c|c|c|c|c|c|c|c|}
\hline & Total & Mean (SD) & Minimum & P25 & Median & P75 & Maximum \\
\hline AECOPD hospitalisations & 84571 & $111.7(41.0)$ & 22.0 & 78.0 & 113.0 & 141.0 & 226.0 \\
\hline \multicolumn{8}{|l|}{ Gender } \\
\hline Male & 53829 & $71.1(25.8)$ & 12.0 & 49.0 & 75.0 & 89.0 & 158.0 \\
\hline Female & 30742 & $40.6(17.7)$ & 7.0 & 27.0 & 39.0 & 53.0 & 110.0 \\
\hline \multicolumn{8}{|l|}{ Age (years) } \\
\hline 0-64 & 13600 & $18.0(8.3)$ & 2.0 & 12.0 & 18.0 & 23.0 & 43.0 \\
\hline$\geq 65$ & 70971 & $93.8(34.3)$ & 19.0 & 67.0 & 95.0 & 118.0 & 189.0 \\
\hline \multicolumn{8}{|l|}{ Environmental variables } \\
\hline Mean temperature $\left({ }^{\circ} \mathrm{C}\right)$ & - & $0.9(5.4)$ & -16.0 & -3.0 & 0.0 & 4.0 & 18.0 \\
\hline Relative humidity (\%) & - & $46.6(20.4)$ & 8.0 & 30.0 & 43.0 & 61.0 & 98.0 \\
\hline Air pressure (hPa) & - & $1025.3(6.5)$ & 1005.0 & 1021.0 & 1026.0 & 1030.0 & 1044.0 \\
\hline Air quality index & - & $126.3(89.2)$ & 17.0 & 61.0 & 97.0 & 170.0 & 485.0 \\
\hline
\end{tabular}

AECOPD, acute exacerbation of chronic obstructive pulmonary disease; P25, 25th percentile; P75, 75th percentile.;

\section{Effects of cold spells under different definitions}

Figure 1 depicts the lag structures of associations between cold spells under nine different definitions and AECOPD hospitalisations of the total population. All cold spells had an impact on the risk of hospitalisations for AECOPD, and most trends of their lagged effects were non-linear with two patterns. One was that the relative risk (RR) of hospitalisations for AECOPD reached a maximum on the days (lag0) of cold spells, then decreased and remained significant for 10-16 days (lag10-lag16). The other one was that the RR became significant on the 3rd or 4th day (lag3 or lag4) after exposure to cold spells, then gradually reached the maximum at about the 8th day (lag8) and lasted until the 15th-17th days (lag15-lag17).

Table 3 shows the cumulative effects of cold spells on AECOPD hospitalisations under different definitions. For each definition, the cumulative relative risk (CRR) increased with longer cumulative lags, with the highest CRR at lag0-21. Among the nine different definitions, the
CRR of cold spells at lag0-21 increased using the definition with longer duration or lower temperature threshold. The maximum CRR over lag0-21 when the temperature threshold was set at the 10th percentile appeared at a duration of $\geq 4$ consecutive days. In comparison, the CRR values at durations of $\geq 3$ consecutive days and $\geq 2$ consecutive days were lower. Likewise, when the duration was set for at least 4 consecutive days, the maximum CRR over lag0-21 appeared at the temperature range defined as $\leq 3 \mathrm{rd}$ percentile, while the CRRs of the temperature threshold at the 5th and 10th percentiles were lower. The lowest Q-AIC value (7769.8) indicating the best model fit was observed in model 3 (table 2). Hence, the optimal cold spell definition was daily mean temperature $\leq 10$ th percentile $\left(-6^{\circ} \mathrm{C}\right)$ for at least 4 consecutive days during the study period. The optimal model was able to find the most significant single-day lagged effect earliest (lag0) and remained significant until the 14th day (lag14) (figure 1).

Table 2 Overview information of cold spells under different definitions

\begin{tabular}{lllllll}
\hline & & Duration & & & \\
Model & Temperature threshold & (days) & Cold spell episodes & Cold spell days & Non-cold spell days & Q-AlC value \\
\hline 1 & $\leq 10 \%\left(-6^{\circ} \mathrm{C}\right)$ & $\geq 2$ & 17 & 77 & 680 & 7819.6 \\
\hline 2 & $\leq 10 \%\left(-6^{\circ} \mathrm{C}\right)$ & $\geq 3$ & 11 & 65 & 692 & 7799.7 \\
\hline 3 & $\leq 10 \%\left(-6^{\circ} \mathrm{C}\right)$ & $\geq 4$ & 6 & 50 & 707 & 7769.8 \\
\hline 4 & $\leq 5 \%\left(-7^{\circ} \mathrm{C}\right)$ & $\geq 2$ & 8 & 37 & 720 & 7794.3 \\
\hline 5 & $\leq 5 \%\left(-7^{\circ} \mathrm{C}\right)$ & $\geq 3$ & 5 & 25 & 732 & 7786.6 \\
\hline 6 & $\leq 5 \%\left(-7^{\circ} \mathrm{C}\right)$ & $\geq 4$ & 3 & 23 & 734 & 7782.5 \\
\hline 7 & $\leq 3 \%\left(-8^{\circ} \mathrm{C}\right)$ & $\geq 2$ & 7 & 19 & 738 & 7786.5 \\
\hline 8 & $\leq 3 \%\left(-8^{\circ} \mathrm{C}\right)$ & $\geq 3$ & 5 & 10 & 747 & 7789.8 \\
\hline 9 & $\leq 3 \%\left(-8^{\circ} \mathrm{C}\right)$ & $\geq 4$ & 2 & & & 7804.4 \\
\hline
\end{tabular}

Q-AIC, quasi-Poisson Akaike information criterion. 
$\leq 10 \% \& \geq 2 d$

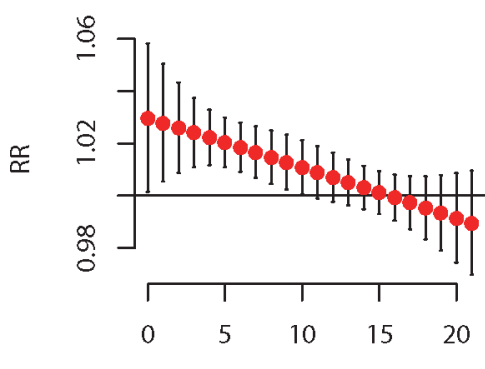

Lag

$\leq 5 \% \& \geq 2 d$

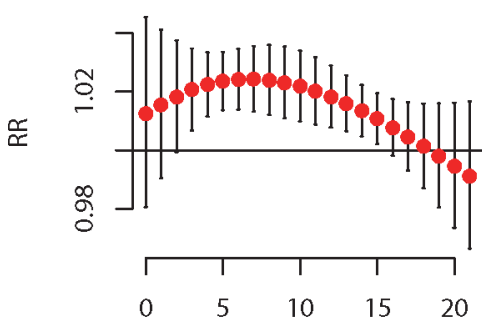

Lag

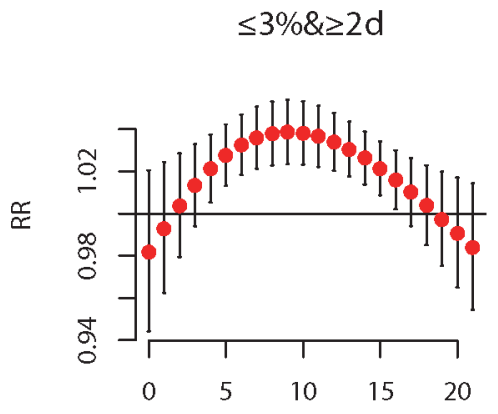

Lag $\leq 10 \% \& \geq 3 d$

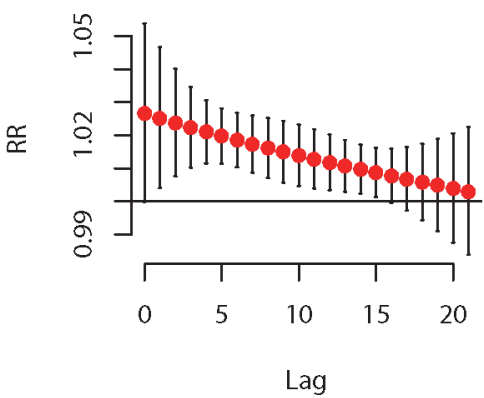

$\leq 5 \% \& \geq 3 d$

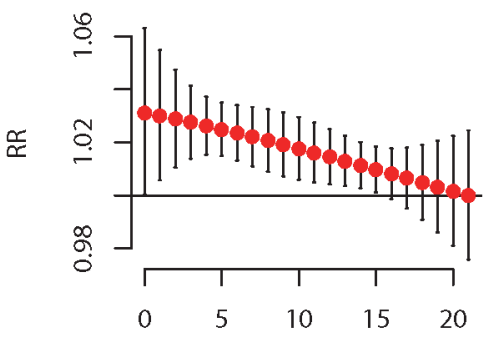

Lag

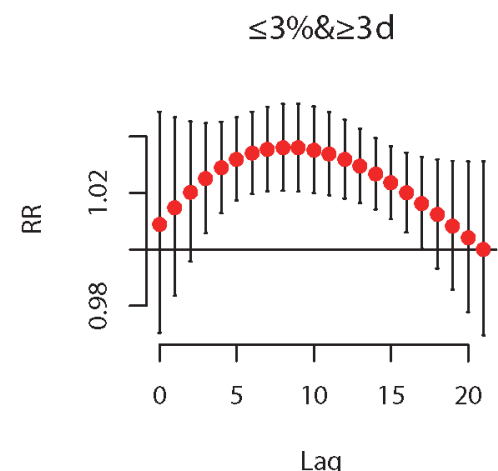

$\leq 10 \% \& \geq 4 d$

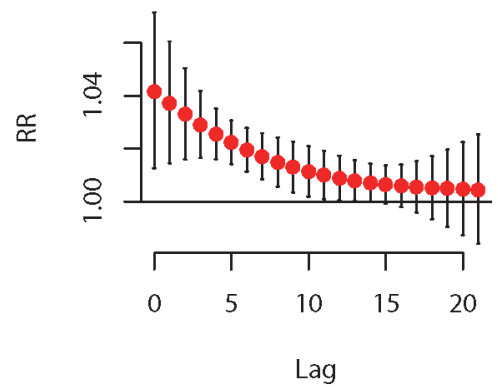

$\leq 5 \% \& \geq 4 d$
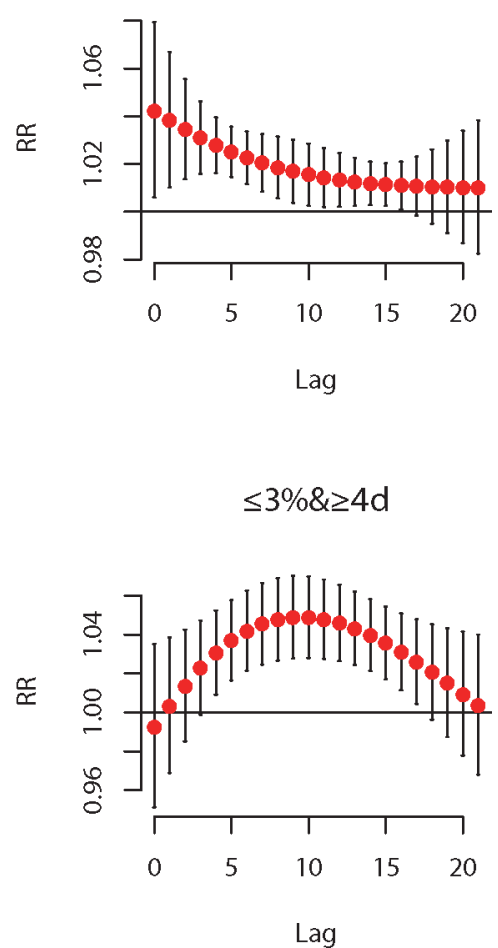

Figure 1 Lag-response relationships between cold spells under different definitions and AECOPD hospitalisations of the total population in Beijing, 2012-2016. AECOPD, acute exacerbation of chronic obstructive pulmonary disease; RR, relative risk.

Table 4 and figure 2 reveal the results for the subgroup analyses of gender and age based on the optimal cold spell definition. The effects of cold spells were similar between male and female patients, with the most significant single-day lagged effect both occurring at lag0 $(\mathrm{Z}=0.041, \mathrm{p}=0.48)$. The cumulative effects at lag0-21 of the two genders also differed slightly $(\mathrm{Z}=-0.730, \mathrm{p}=0.23)$. Additionally, in the subgroups stratified by age, the most significant single-day lagged effect and cumulative effect for people aged $\geq 65$ years were at lag0 and lag0-21, respectively. However, no significant effect of cold spells was observed in those aged 0-64 years. The results of sensitivity analyses indicated that the effect estimates of cold spells under the optimal definition on AECOPD hospitalisations were still robust (see online supplemental tables 1-5).

\section{DISCUSSION}

In this study, we showed that cold spells were associated with increased hospitalisations for AECOPD. The adverse impacts of cold spells varied with durations and intensities. Based on the statistical model fit, the optimal definition of cold spells was daily mean temperature less than or equal to the 10th percentile lasting for at least 4 consecutive days during the study period. The elderly seemed more sensitive to cold spells than the younger, while the susceptibility difference between genders was not noticeable.

Our finding is in accordance with previous studies reporting an excess of AECOPD hospitalisations, ${ }^{15}$ emergency visits ${ }^{33}$ and mortality ${ }^{4634}$ associated with cold spells. For instance, Monteiro et $a l^{15}$ reported significant effects 
Table 3 Cumulative relative risk of cold spells under different definitions on AECOPD hospitalisations of the total population in Beijing, 2012-2016

\begin{tabular}{lllll}
\hline & CRR $(95 \%$ Cl) & & & \\
\cline { 2 - 6 } Definition & Lag0 & Lag0-7 & Lag0-14 & Lag0-21 \\
\hline$\leq 10 \%$ and $\geq 2$ days & $1.030(1.002 \text { to } 1.058)^{\star}$ & $1.200(1.087 \text { to } 1.326)^{\star}$ & $1.278(1.134 \text { to } 1.439)^{\star}$ & $1.236(1.055 \text { to } 1.448)^{\star}$ \\
\hline $10 \%$ and $\geq 3$ days & $1.027(1.000 \text { to } 1.054)^{\star}$ & $1.188(1.084 \text { to } 1.303)^{\star}$ & $1.299(1.166 \text { to } 1.448)^{\star}$ & $1.353(1.161 \text { to } 1.577)^{\star}$ \\
\hline$\leq 10 \%$ and $\geq 4$ days & $1.042(1.013 \text { to } 1.072)^{\star}$ & $1.249(1.136 \text { to } 1.374)^{\star}$ & $1.343(1.206 \text { to } 1.496)^{\star}$ & $1.394(1.193 \text { to } 1.630)^{\star}$ \\
\hline $5 \%$ and $\geq 2$ days & $1.012(0.980$ to 1.045$)$ & $1.173(1.055 \text { to } 1.304)^{\star}$ & $1.344(1.188 \text { to } 1.519)^{\star}$ & $1.354(1.141 \text { to } 1.608)^{\star}$ \\
\hline $5 \%$ and $\geq 3$ days & $1.031(1.000 \text { to } 1.063)^{\star}$ & $1.235(1.114 \text { to } 1.369)^{\star}$ & $1.381(1.220 \text { to } 1.563)^{\star}$ & $1.428(1.206 \text { to } 1.692)^{\star}$ \\
\hline$\leq 5 \%$ and $\geq 4$ days & $1.042(1.006 \text { to } 1.079)^{\star}$ & $1.268(1.132 \text { to } 1.421)^{\star}$ & $1.404(1.234 \text { to } 1.598)^{\star}$ & $1.511(1.262 \text { to } 1.809)^{\star}$ \\
$\leq 3 \%$ and $\geq 2$ days & $0.982(0.944$ to 1.021$)$ & $1.113(0.960$ to 1.290$)$ & $1.412(1.171 \text { to } 1.703)^{\star}$ & $1.444(1.113 \text { to } 1.873)^{\star}$ \\
\hline$\leq 3 \%$ and $\geq 3$ days & $1.009(0.970$ to 1.049$)$ & $1.217(1.051 \text { to } 1.411)^{\star}$ & $1.525(1.264 \text { to } 1.841)^{\star}$ & $1.659(1.278 \text { to } 2.154)^{\star}$ \\
$\leq 3 \%$ and $\geq 4$ days & $0.992(0.951$ to 1.035$)$ & $1.201(0.999$ to 1.443$)$ & $1.644(1.261 \text { to } 2.145)^{\star}$ & $1.889(1.315 \text { to } 2.712)^{\star}$ \\
\hline
\end{tabular}

${ }^{*} \mathrm{P}<0.05$.

AECOPD, acute exacerbation of chronic obstructive pulmonary disease; CRR, cumulative relative risk.

of cold spells identified by various indices on COPD hospitalisations with a lagged effect of at least 2 weeks. Several underlying mechanisms may explain for elevated COPD morbidity and mortality attributable to extremely cold events. First, cold exposure has been found to be related to a decline in lung function (forced expiratory volume in $1 \mathrm{~s}$, forced vital capacity and peak expiratory flow) among patients with COPD. ${ }^{35}{ }^{36}$ Second, Shephard and Shek ${ }^{37}$ reported that cold air could directly induce bronchoconstriction, leading to excessive dyspnoea in patients with COPD. Third, cold exposure may suppress the immune response and increase susceptibility to viral infections in humans. ${ }^{38}$ Meanwhile, the transmission efficiency of the influenza virus is inversely correlated with ambient temperature. ${ }^{39}$ Fourth, cold temperature may provoke airway inflammation and mucin hypersecretion in airway epithelium, which results in COPD morbidity and mortality by blocking airways and causing recurrent infections. ${ }^{40} 4$

We found that the CRR values of AECOPD hospitalisations increased with longer duration and higher intensity of cold spells. Some prior studies had similar findings, ${ }^{2021}$ indicating that both the duration and the intensity affect the health risks of cold spells. According to the minimum
Q-AIC value criterion, the optimal definition of cold spells was daily average temperature at or below the 10th percentile for 4 or more consecutive days. Compared with other definitions, this one had lower intensity and longer duration, and the most significant single-day lagged effect of cold spells on AECOPD hospitalisations appeared earliest $(\operatorname{lag} 0)$. Our results agree with a study in Porto showing that moderately low temperature for long periods contributed to COPD exacerbation greater than extremely low temperature with shorter-lasting days. ${ }^{15}$ However, studies on some other diseases defined the optimal cold spell with the threshold at the fifth percentile or of at least 2 days' duration, ${ }^{21} 32$ indicating different definitions may apply to different outcomes. In addition, some studies reported the temporal changes in people's adaption capacities to cold spells during recent decades under climate change. ${ }^{5} 42$ Overall, more effective cold spell definitions and warning systems adapted to regional climate, specific diseases and dynamic changes of the population's sensitivity should be further studied and implemented in the future.

In the subgroup analyses based on the optimal cold spell definition, we found that the effects of cold spells on AECOPD hospitalisations were more significant in the

Table 4 Cumulative relative risk of cold spells† on AECOPD hospitalisations stratified by gender and age in Beijing, 20122016

\begin{tabular}{lllll}
\hline & CRR $(\mathbf{9 5 \%}$ Cl) & & \\
\cline { 2 - 6 } Subgroup & Lag0 & Lag0-7 & Lag0-14 & Lag0-21 \\
\hline Male & $1.042(1.011 \text { to } 1.074)^{\star}$ & $1.243(1.123 \text { to } 1.375)^{\star}$ & $1.316(1.173 \text { to } 1.477)^{\star}$ & $1.342(1.136 \text { to } 1.586)^{\star}$ \\
\hline Female & $1.041(1.005 \text { to } 1.077)^{\star}$ & $1.257(1.119 \text { to } 1.411)^{\star}$ & $1.383(1.215 \text { to } 1.574)^{\star}$ & $1.476(1.211 \text { to } 1.783)^{\star}$ \\
Age $<65$ & $1.017(0.972$ to 1.064$)$ & $1.120(0.963$ to 1.303$)$ & $1.159(0.977$ to 1.376$)$ & $1.107(0.862$ to 1.422$)$ \\
\hline Age $\geq 65$ & $1.046(1.017 \text { to } 1.077)^{\star}$ & $1.275(1.158 \text { to } 1.404)^{\star}$ & $1.382(1.240 \text { to } 1.540)^{\star}$ & $1.456(1.244 \text { to } 1.705)^{\star}$ \\
\hline
\end{tabular}

${ }^{*} \mathrm{P}<0.05$.

†The optimal cold spell definition was daily mean temperature $\leq 10$ th percentile $\left(-6^{\circ} \mathrm{C}\right)$ for at least 4 consecutive days during the study period. AECOPD, acute exacerbation of chronic obstructive pulmonary disease; CRR, cumulative relative risk. 
Male

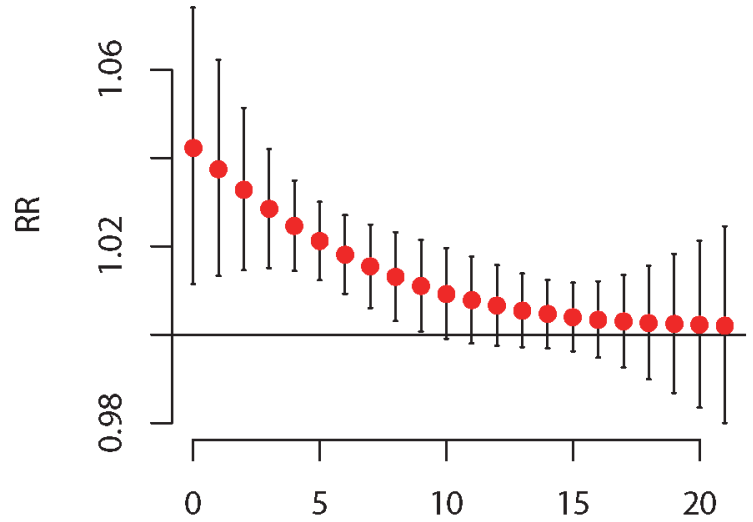

Lag

Age $<65$

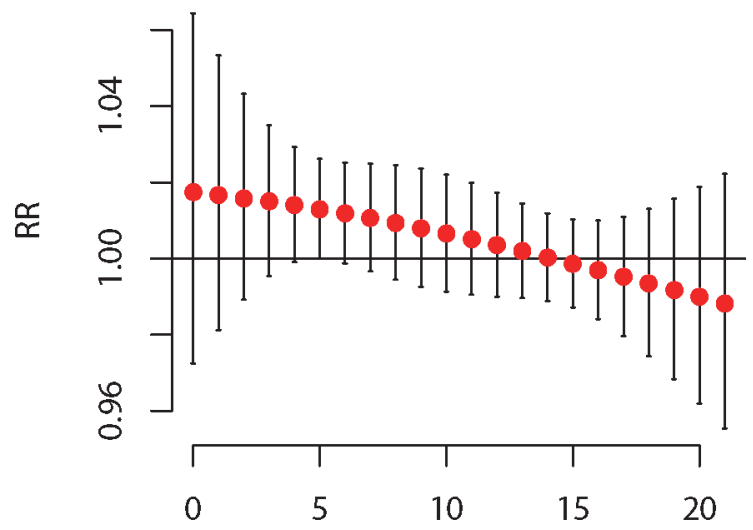

Lag
Female

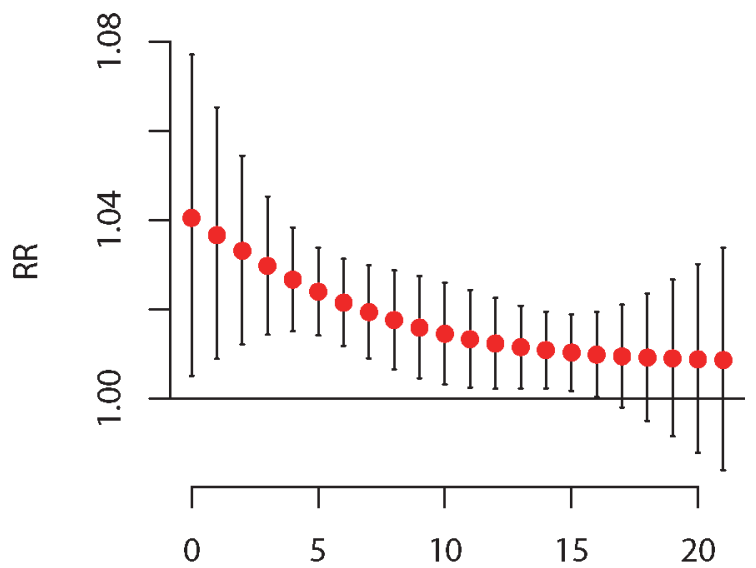

Lag

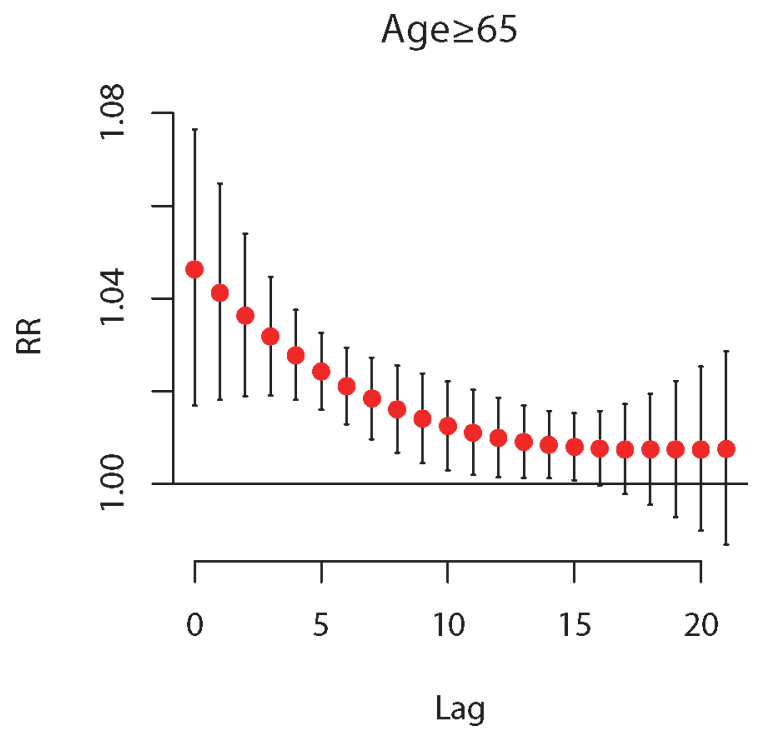

Figure 2 Lag-response relationships between cold spells and AECOPD hospitalisations stratified by gender and age in Beijing, 2012-2016. AECOPD, acute exacerbation of chronic obstructive pulmonary disease; RR, relative risk.

elderly (aged $\geq 65$ years) than people aged 0-64 years. This finding is consistent with previous studies. ${ }^{42}{ }^{43}$ The reasons may point to reduced thermoregulatory ability, higher prevalence of chronic diseases ${ }^{20} 34$ and impaired immunity ${ }^{44}$ in the elderly. Note that ageing is one of the risk factors of COPD, and most patients in our study were over 64 , giving more power to achieve statistical significance. However, some studies showed the opposite results. ${ }^{6}$ It was speculated that the younger tend to spend more time outdoors, increasing their opportunities for exposure to extremely cold temperature. In terms of gender, we found similar impacts of cold spells among male and female patients, which corresponds with previous studies. ${ }^{412} 43$

Our study has significant public health implications for local prevention of AECOPD, development of early warning systems and rational allocation of medical and health resources to mitigate the COPD burden caused by cold spells. We showed substantial effects of cold spells on the risk of AECOPD hospitalisations with a lagged effect of about 3 weeks, urging for effective and practical guidelines for preventions, particularly for patients with COPD during cold spells in China. Both the government and individuals should take practical actions. The meteorological departments should improve early warning systems with timely forecast and publication of extremely cold events. Moreover, the government should exert great efforts to raise public awareness of the health hazards of cold spells and ensure adequate public and medical services coping with cold spells. ${ }^{4}$ As for individuals, it has been reported that staying indoor and wearing warm clothing could reduce mortality in extremely cold weather. ${ }^{45}$ Tseng et al ${ }^{12}$ suggested that patients with COPD who received inhaled medicine were less affected by cold 
temperature-related COPD exacerbation. Therefore, keeping warm, minimising outdoor activities and taking medications regularly are vital measures to fight against cold spells for individuals with COPD, especially for the elderly.

The main strengths of our study are as follows: First, to the best of our knowledge, this is the first study to investigate the relationship between cold spells and AECOPD hospitalisations in China. Second, we controlled air quality and influenza epidemics as confounding factors, which were not included by some previous studies. Lee $e t$ $a l^{13}$ have reported that a higher influenza virus detection rate was correlated with AECOPD. ${ }^{14}$ A previous study from Beijing has found significant associations between shortterm exposures to air pollution and hospitalisations for AECOPD. ${ }^{23}$ Existing literature has also shown that both air pollution and influenza epidemics could contribute to cold-related health effects. ${ }^{46}{ }^{47}$ Moreover, air pollutants may interact with viral infections to precipitate AECOPD rather than acting alone. Feng et al $t^{47}$ reported that ambient particulate matter with aerodynamic diameter $<2.5 \mu \mathrm{m}$ was associated with risk of influenza-like illness in Beijing during the influenza season. Further research on the interactions among cold spells, air pollution and influenza on AECOPD is therefore needed. Third, we identified the elderly to be more vulnerable to cold spells by stratified analyses, guiding more targeted prevention strategies.

The study also has several limitations. First, as an ecological study, the association between cold spells and AECOPD hospitalisations does not imply causality. Second, different socioeconomic status or other factors at an individual level might be confounding factors and were not considered in the association. Third, the meteorological variables and AQI were all from monitoring stations, not reflecting the individual level of exposures. Moreover, people are more likely to stay indoors with heating systems during extremely cold days in northern China, so inevitable exposure measurement errors may lead to bias. Fourth, due to the limited availability of local data, the positive rates of influenza isolations were from the northern part of China, but not only Beijing. Further studies with local influenza data included as a continuous variable in the model are warranted. Lastly, the data from only one city weaken the extrapolation validity of the study.

\section{CONCLUSION}

Our study demonstrates that short-term exposure to cold spells is associated with an increased risk of AECOPD hospitalisations. The cumulative effects increased with the intensities and the durations of cold spells. The elderly are more vulnerable to AECOPD hospitalisations during cold spell periods. These findings provide scientific foundations for comprehensive public health strategies to reduce cold spell-related AECOPD hospitalisations in Beijing, China.
Author affiliations

${ }^{1}$ Department of Medicine, Peking Union Medical College Hospital, Peking Union Medical College and Chinese Academy of Medical Sciences, Beijing, China

${ }^{2}$ Department of Physiotherapy, Peking Union Medical College Hospital, Peking Union Medical College and Chinese Academy of Medical Sciences, Beijing, China ${ }^{3}$ Department of Biochemistry, The State Key Laboratory of Medical Molecular Biology, Institute of Basic Medical Sciences, Chinese Academy of Medical Sciences, Peking Union Medical College, Beijing, China

Contributors ZF obtained the original data and funding. ZF, $Y L$ and $Y C$ designed the study. DK, XL, JF, YoZ and ZC preprocessed the data. YL, YC and YaZ analysed the data. $Y L$ and $Y C$ drafted the manuscript. $X Z, K X, C J$ and $Z F$ reviewed and edited the manuscript. All authors have read and approved the final manuscript. ZF is the study guarantor.

Funding This work was supported by the National Key Research and Development Plan (2017YFC0211703), National 973 Project (2015CB553400), Chinese Academy of Medical Sciences (CAMS) Initiative for Innovative Medicine (CAMS 2016ZX310181-5/4, CAMS 2017-I2M-2-001), and National Natural Science Foundation (91643208, 41450006).

Competing interests None declared.

Patient consent for publication Not required.

Ethics approval This study was approved by the ethical review committee of Peking Union Medical College Hospital.

Provenance and peer review Not commissioned; externally peer reviewed.

Data availability statement All data relevant to the study are included in the article or uploaded as supplemental information. No additional data are available.

Supplemental material This content has been supplied by the author(s). It has not been vetted by BMJ Publishing Group Limited (BMJ) and may not have been peer-reviewed. Any opinions or recommendations discussed are solely those of the author(s) and are not endorsed by BMJ. BMJ disclaims all liability and responsibility arising from any reliance placed on the content. Where the content includes any translated material, BMJ does not warrant the accuracy and reliability of the translations (including but not limited to local regulations, clinical guidelines, terminology, drug names and drug dosages), and is not responsible for any error and/or omissions arising from translation and adaptation or otherwise.

Open access This is an open access article distributed in accordance with the Creative Commons Attribution 4.0 Unported (CC BY 4.0) license, which permits others to copy, redistribute, remix, transform and build upon this work for any purpose, provided the original work is properly cited, a link to the licence is given, and indication of whether changes were made. See: https://creativecommons.org/ licenses/by/4.0/.

\section{ORCID iDs}

Jia Fu http://orcid.org/0000-0003-1432-0323

Zhongjie Fan http://orcid.org/0000-0002-2732-0659

\section{REFERENCES}

1 IPCC. Climate change 2014: synthesis report. Contribution of working groups I, II and III to the fifth assessment report of the intergovernmental panel on climate change [Core writing team, R.K. Pachauri and L.A. Meyer (eds)]. Geneva, Switzerland: IPCC, 2014: 151.

2 Cohen J, Screen JA, Furtado JC, et al. Recent Arctic amplification and extreme mid-latitude weather. Nat Geosci 2014;7:627-37.

3 Zhang J, Tian W, Chipperfield MP, et al. Persistent shift of the Arctic polar vortex towards the Eurasian continent in recent decades. Nat Clim Chang 2016;6:1094-9.

4 Chen J, Yang J, Zhou M, et al. Cold spell and mortality in 31 Chinese capital cities: definitions, vulnerability and implications. Environ Int 2019;128:271-8.

5 Lee W, Choi HM, Lee JY, et al. Temporal changes in mortality impacts of heat wave and cold spell in Korea and Japan. Environ Int 2018;116:136-46.

6 Han J, Liu S, Zhang J, et al. The impact of temperature extremes on mortality: a time-series study in Jinan, China. BMJ Open 2017;7:e014741.

7 Rabe KF, Watz H. Chronic obstructive pulmonary disease. The Lancet 2017;389:1931-40. 
8 López-Campos JL, Tan W, Soriano JB. Global burden of COPD. Respirology 2016;21:14-23.

9 Donaldson GC, Goldring JJ, Wedzicha JA. Influence of season on exacerbation characteristics in patients with COPD. Chest 2012;141:94-100.

10 McCormack MC, Paulin LM, Gummerson CE, et al. Colder temperature is associated with increased COPD morbidity. Eur Respir J 2017;49:1601501.

11 Chaturvedi S, Tseng C-M, Chen Y-T. The effect of cold temperature on increased exacerbation of chronic obstructive pulmonary disease: a nationwide study. PloS one 2013;8:e57066.

12 Tseng C-M, Chen Y-T, Ou S-M, et al. The effect of cold temperature on increased exacerbation of chronic obstructive pulmonary disease: a nationwide study. PLoS One 2013;8:e57066.

13 Lee J, Jung HM, Kim SK, et al. Factors associated with chronic obstructive pulmonary disease exacerbation, based on big data analysis. Sci Rep 2019;9:6679.

14 Hajat S, Armstrong B, Baccini M, et al. Impact of high temperatures on mortality: is there an added heat wave effect? Epidemiology 2006;17:632-8.

15 Monteiro A, Carvalho V, Góis J, et al. Use of "Cold Spell" indices to quantify excess chronic obstructive pulmonary disease (COPD) morbidity during winter (November to March 2000-2007): case study in Porto. Int J Biometeorol 2013;57:857-70.

16 Wang C, Xu J, Yang L, et al. Prevalence and risk factors of chronic obstructive pulmonary disease in China (the China Pulmonary Health [CPH] study): a national cross-sectional study. Lancet 2018;391:1706-17.

17 Xie H, Yao Z, Zhang Y, et al. Short-Term effects of the 2008 cold spell on mortality in three subtropical cities in Guangdong Province, China. Environ Health Perspect 2013:121:210-6.

18 Zhou B, Gu L, Ding Y, et al. The great 2008 Chinese ice storm: its Socioeconomic-Ecological impact and sustainability lessons learned. Bull Am Meteorol Soc 2011:92:47-60.

19 Ban J, Huang L, Chen C, et al. Integrating new indicators of predictors that shape the public's perception of local extreme temperature in China. Sci Total Environ 2017:579:529-36.

20 Wang L, Liu T, Hu M, et al. The impact of cold spells on mortality and effect modification by cold spell characteristics. Sci Rep 2016;6:38380.

21 Gao J, Yu F, Xu Z, et al. The association between cold spells and admissions of ischemic stroke in Hefei, China: modified by gender and age. Sci Total Environ 2019;669:140-7.

22 Liu X, Kong D, Fu J, et al. Association between extreme temperature and acute myocardial infarction hospital admissions in Beijing, China: 2013-2016. PLoS One 2018;13:e0204706.

23 Liang L, Cai Y, Barratt B, et al. Associations between daily air quality and hospitalisations for acute exacerbation of chronic obstructive pulmonary disease in Beijing, 2013-17: an ecological analysis. Lancet Planet Health 2019;3:e270-9.

24 Wedzicha JA, Seemungal TAR. Copd exacerbations: defining their cause and prevention. Lancet 2007;370:786-96.

25 Stafoggia M, Samoli E, Alessandrini E, et al. Short-term associations between fine and coarse particulate matter and hospitalizations in southern Europe: results from the MED-PARTICLES project. Environ Health Perspect 2013;121:1026-33.

26 Solimini AG, Renzi M. Association between air pollution and emergency room visits for atrial fibrillation. Int J Environ Res Public Health 2017;14:661.

27 Cowling BJ, Wong IOL, Ho L-M, et al. Methods for monitoring influenza surveillance data. Int J Epidemiol 2006;35:1314-21.
28 Song X, Wang S, Li T, et al. The impact of heat waves and cold spells on respiratory emergency department visits in Beijing, China. Sci Total Environ 2018;615:1499-505.

29 Guo Y, Jiang F, Peng L, et al. The association between cold spells and pediatric outpatient visits for asthma in Shanghai, China. PLoS One 2012; 7:e42232.

30 Gasparrini A. Modeling exposure-lag-response associations with distributed lag non-linear models. Stat Med 2014;33:881-99.

31 Cheng Q, Wang X, Wei Q, et al. The short-term effects of cold spells on pediatric outpatient admission for allergic rhinitis in Hefei, China. Sci Total Environ 2019;664:374-80.

32 Liang Z, Wang $P$, Zhao Q, et al. Effect of the 2008 cold spell on preterm births in two subtropical cities of Guangdong Province, southern China. Sci Total Environ 2018;642:307-13.

33 de'Donato FK, Leone M, Noce D, et al. The impact of the February 2012 cold spell on health in Italy using surveillance data. PLoS One;8:e61720.

34 Lin Z, Gu Y, Liu C, et al. Effects of ambient temperature on lung function in patients with chronic obstructive pulmonary disease: a time-series panel study. Sci Total Environ 2018;619-620:360-5.

35 Donaldson GC, Seemungal T, Jeffries DJ, et al. Effect of temperature on lung function and symptoms in chronic obstructive pulmonary disease. Eur Respir J 1999;13:844-9.

36 Koskela HO, Koskela AK, Tukiaineu HO. Bronchoconstriction due to cold weather in COPD. The roles of direct airway effects and cutaneous reflex mechanisms. Chest 1996;110:632-6.

37 Shephard RJ, Shek PN. Cold exposure and immune function. Can J Physiol Pharmacol 1998;76:828-36.

38 Lowen AC, Mubareka S, Steel J, et al. Influenza virus transmission is dependent on relative humidity and temperature. PLoS Pathog 2007;3:e151-6.

39 Li M, Li Q, Yang G, et al. Cold temperature induces mucin hypersecretion from normal human bronchial epithelial cells in vitro through a transient receptor potential melastatin 8 (TRPM8)mediated mechanism. J Allergy Clin Immunol 2011;128: 626-34.

40 Juan Y, Haiqiao W, Xie W, et al. Cold-inducible RNA-binding protein mediates airway inflammation and mucus hypersecretion through a post-transcriptional regulatory mechanism under cold stress. Int $J$ Biochem Cell Biol 2016;78:335-48.

41 Chung $\mathrm{Y}, \mathrm{Noh} \mathrm{H}$, Honda $\mathrm{Y}$, et al. Temporal changes in mortality related to extreme temperatures for 15 cities in northeast Asia: adaptation to heat and maladaptation to cold. Am J Epidemiol 2017;185:907-13.

42 Ma W, Yang C, Chu C, et al. The impact of the 2008 cold spell on mortality in Shanghai, China. Int J Biometeorol 2013;57:179-84.

43 Goodwin JS. Decreased immunity and increased morbidity in the elderly. Nutr Rev 1995;53:S41-6.

44 Donaldson GC, Ermakov SP, Komarov YM, et al. Cold related mortalities and protection against cold in Yakutsk, eastern Siberia: observation and interview study. BMJ 1998;317:978-82.

45 Qiu H, Tan K, Long F, et al. The burden of COPD morbidity attributable to the interaction between ambient air pollution and temperature in Chengdu, China. Int J Environ Res Public Health 2018:15:492

46 Huynen MM, Martens P, Schram D, et al. The impact of heat waves and cold spells on mortality rates in the Dutch population. Environ Health Perspect 2001;109:463-70.

47 Feng C, Li J, Sun W, et al. Impact of ambient fine particulate matter (PM2.5) exposure on the risk of influenza-like-illness: a time-series analysis in Beijing, China. Environmental Health 2016;15:17. 